\title{
A preliminary survey of the herbaceous flora of the Acharya Jagadish Chandra Bose Indian Botanic Garden (AJCBIBG), Howrah, W.B., India.
}

Hameed S.S., Panda S.P.*, Sharief M.U., Sreekumar P.V., Mahapatra H.S. and A. Pramanik AJC Bose Indian Botanic Garden, Botanical Survey of India, Howrah -711103 (WB), India.

Received: May 14, 2016; Accepted: May 27, 2016.

\begin{abstract}
The Acharya Jagadish Chandra Bose Indian Botanic Garden (AJCBIBG) previously known as Indian Botanic Garden, Howrah, is a historic old garden. This botanic garden has a special position among all the botanic gardens that the world having. In earlier time this garden witnessed as the centre of plant introduction. Till then AJCBIBG served as a centre for ex-situ conservation of many RET species collected from different parts of the globe. The rich and diverse floristic wealth of this garden makes it unique and very special. AJCBIBG is a living repository of 1377 species of plants (excluding herbs). The garden abode a rich herbaceous flora due to its congenial climate. However, records on the herbaceous plants dwelling in AJCBIBG are very scanty. Taking this into account the present study aimed at enlisting the herbaceous flora of the garden. A checklist of plants belonging to various families has been provided in this communication.
\end{abstract}

Key Words: Survey; Herbaceous flora; AJCBIBG

\section{Introduction}

Indian Botanic Garden (IBG), Howrah formerly known as 'Company Bagan', the Royal Botanic Garden, Kolkata, at present AJC Bose Indian Botanic Garden (AJCBIBG), Howrah, is one of the best landscaped gardens in the world. The original history of AJCBIBG is almost similar to the Kew Garden in England which is situated on the bank of the river Thames, a few miles away from London. The Kew garden is about 50 years younger to AJCBIBG, Howrah which owes its interests in the Botany of Royalty but the latter has been established with economic and scientific aims (Biswas, 1938). The Royal Botanic Garden, Kolkata, on the contrary, situated on the bank of river Hooghly a few kilometers away from Kolkata, initiated in a vast area of about 300 acres of land and it was regarded as the largest and one of the oldest botanic gardens in the world till the middle of $19^{\text {th }}$ century and now occupies an area of 273 acres. At present, the garden with an area of 273 acres and being a living repository of 1377 species of plants possesses 25 divisions and 24 interconnected lakes, and the lakes are connected to the Ganges through sluices for the regular inlet and outlet of water (Map.1). The garden is a unique place of learning \& rich array of curiosity and occupies matchless attractions like the 'Great Banyan 'Tree', a living wonder in the plant kingdom; the Large Palm House containing rich collection of palms including Lodoicea maldivica (J.F.Gmel.) Pers. (the Double Coconut palm); Branching palm [Hyphaene thebaica (L.) Mart.] introduced from Egypt; the century Palm (Corypha utan Lam.); the Giant Water Lily (Victoria amazonica (Poepp.) J.C. Sowerby and V. cruziana A.D. Orb.) brought from Amazon river; the queen of flowering trees (Amberstia nobilis Wall.) a native of Burma; the mountain rose or Venezuelan rose

\section{Corresponding Author}

Dr. Sitaram Prasad Panda,

Scientist 'B'

AJC Bose Indian Botanic Garden,

Botanical Survey of India

Howrah- 711103 (West Bengal), India.
(Brownea sp.); the Baobab tree or Kalpavriksh (Adansonia digitata L.) native of Africa; the Rosogolla tree (Chrysobyllum cainito L.); the Cannon ball tree (Couroupita guianensis Aubl.); the African Sausage tree (Kigelia africana (Lam.) Benth.) and the mad tree (Pterigota alata (Roxb.) R. Br. var. irregularis) and the 'Candle Stick Tree' (Parmentiera cereifera Seem.) etc., are a few to mention.

Presently Acharya Jagadish Chandra Bose Indian Botanic Garden is taken as a centre of conservation of plant resources from their extinction. This garden serves as a living repository of plants of a country and also of selected exotic species, and a "safe abode" for the rare and endemic plants. As a result it houses the germplasm collection of selected economic, ornamental and medicinal plants and their wild progenitors. The garden also act to promote educational programmes in order to generate awareness about the value of trees and other curious, beautiful, interesting plants with delightful landscaping and display. This garden also organizes flower, foliage and plant shows etc.; exchange of viable seeds, seedlings and other propagules as well. As a whole, it acts as a data bank of information and documentation on holdings in the botanic garden.

AJCBIBG, Howrah also played a significant role in introducing, multiplying and distributing many commercially important plants from various parts of the world. Introduction of some of the notable species directly influenced the welfare of people and economic development of the country. Tea (Camellia sinensis var. assamica (J.W. Mast.) Kitam.), Cinchona (Cinchona pubescens Vahl.), Rubber (Hevea brasiliensis (Willd. ex A. Juss.) Mull.Arg.), Mahagony etc. were first introduced in the garden and 
subsequently transferred to other parts. The garden has served as a platform for acclimatization and distribution of a number of economic and ornamental plants of Agri- Horticultural importance of Indian and foreign origin. Some of the important species are Amberstia nobilis Wall. (the Queen of flowering trees) introduced from Burma in 1826 by Nathaniel Wallich; Allamanda sp. in 1803 by W. Hamilton; Bongainvillea sp. in 1803 by W. Hamilton; Garden Croton in 1798 by C. Smith; Australian pine in 1798; Crescentia cujete L. (Calabash tree) in 1795 by W. Hamilton; Lodoicea maldivica (J.F.Gmel.) Pers. (the Double Cocunut) in 1874 by Sir George King; Passion flower in 1797;
Chinese rose in 1794 by William Roxburgh; Victoria amazonica (Poepp.) J.C. Sowerby (the Giant Water lily) in 1873 by Sir George King. The foregoing examples are only a few of them. A large number of economic and spice species like Cardamom, Cinchona, Cinnamon, Coffee, Cotton, Indigo, Nutmeg, Pepper, Clove, Sugarcane, Potato, Sago, Teak etc., and other species used as forage, fodder, oil, fruit, fibre, timber and ornamental plants were first introduced into this historic Garden. Multiplication of most of the introduced species carried out in the Garden itself and distributed to different parts of the country for commercial cultivation.

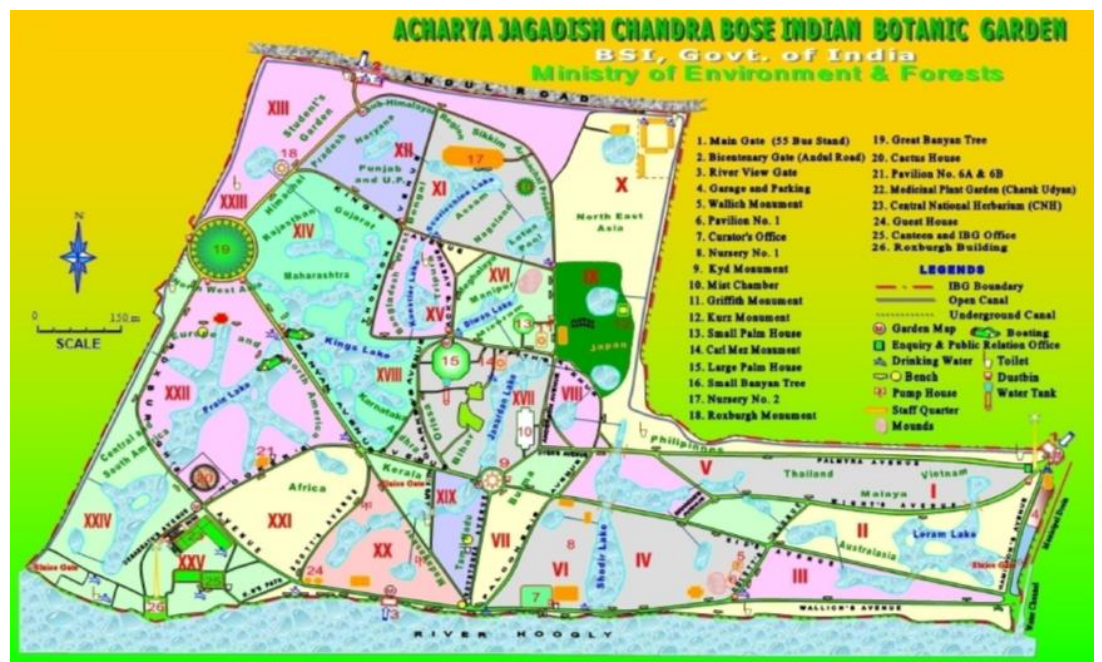

Map.1. Layout map of AJC Bose Indian Botanic Garden, BSI, Howrah

Well before the Rio Earth Summit i.e. the way back in 1987 AJC Bose Indian Botanic Garden, Howrah has adopted and implemented a wellplanned decision of Introducing Rare, Endangered and Threatened (RET) indigenous plant species, in the 'Annual Action Plans', prior to their extinction from the wild and to multiply and conserve them so as to check the loss of species. After the Rio Convention in 1992 the trend of introducing RET species in AJCBIBG has increased many folds and annually a large number of exclusive RET species being collected from the wild and introduced and multiplied for the purpose of effective conservation.

In the last eight years, i.e. from 2008 - 2015, AJCBIBG officials concentrated only in the collection of Endemic, Endangered \& Threatened (RET) species. This is mainly due to the loss of many key species from the wild, because of habitat loss a number of species is being pushed annually into the IUCN list of threatened plants. Nevertheless, the mission of introducing threatened species from the phytogeographically and ecologically fragile Western Ghats, Eastern Ghats, North East India and Andaman \& Nicobar Islands continues to be a major target of AJCBIBG under the Annual Action Plans.

\section{Materials and Methods}

The current work is an exhaustive division wise survey of herbaceous plants of AJCBIBG, Howrah. It remained as a wide gap in the knowledge area since after the publication of 'Non-herbaceous Phanerogams of Indian Botanic Garden' by Sen \& Nasker in 1965 in which the distribution of respective species in their concerned divisions have been mentioned; but deals only the trees and shrubs. The subsequent publications (Gage, 19I2; Biswas, 1938; Chowdhury \& Pandey, 2007) also have not dealt the herbaceous flora. Recently Debnath et al. (2014) published the Census of Plants of AJCBIBG. They also did not paid attention to enlist the rich herbaceous flora of this garden.

Realizing this, regular field surveys of different divisions of the AJCBIBG were made for enlisting the herbs. The detailed information regarding associate plants, ecology, other field characters were recorded. The plants were identified in consultation with modern floras and monographs. Information regarding utility was also recorded. The plants are arranged alphabetically along with their family. However, grasses and sedges are not enlisted in this communication. 


\section{Enumeration:}

1. Abutilon indicum

Acalypha indica $\mathrm{I}$.

Acanthus ilicifolius L.

Achyranthes aspera $\mathrm{L}$.

Acorus calamus L.

Adiantum farleyense Moori

Adiantum tenarum Swartz

Agave decipiens Baker

Ageratum conyzoides L.

Ageratum haustorianum Mill.

Alisma plantago L.

Alocasia indica Schott.

Alocasia macrorrbiza Schott.

Aloe vera (L.) Burm.f

Aloysia citriodora Palau.

Alternanthera sessilis (L.) R.Br. ex DC.

Amaranthus caudatus L.

Ammania laccifera L.

Amorphophalus paenifolius (Dennst.) Nico.

Ampelocissus latifolia (Roxb.) Planch.

Andrographis paniculata (Burm.f) Nees

Anisomeles indica (L.) Kuntze

Antigonon leptopus Hook. \& Arn.

Aponogeton crispus Thunb.

Aponogeton natans (L.) Engl. \& K. Krause

Argyreia cuneata (Willd.) Ker-Gawl.

Artemisia indica Willd.

Artemisia vulgaris $\mathrm{L}$.

Asclepias curassavica $\mathrm{L}$

Asystasia chelonoides Nees. var. quadrangularis

31. Asystasia gangetica (L.) T. Anderson

2. Basella alba var. rubra L.

33. Bidens pilosa $\mathrm{L}$.

34. Boehmeria nivea (L.) Gaudich.

5. Boerhavia diffusa L.

Cardiospermum helicacabum $\mathrm{L}$

Cassia alata $\mathrm{L}$.

Cassia biflora $\mathrm{L}$

Cassia sophera $\mathrm{L}$.

Cassia tora $\mathrm{L}$

41. Cassytha filiformis $\mathrm{L}$

42. Catharanthus roseus (L.) G. Don

43. Cayratia pedata (Lam.) Juss. ex Gagnep.

44. Cayratia trifolia (L.) Domin

Celosia argentia $\mathrm{L}$.

Vitaceae

Celosia argentia L. var. cristata (L.) Kuntze Amaranthaceae

Centella asiatica (L.) Urb.

Ceratophyllum demersum $\mathrm{L}$.

(L.) Kuntze

Apiaceae

Ceratophyllaceae

Ceratopteris sliquosa (L.) Copeland Parkeriaceae (Fern)

Cheiranthus cheiri L. Brassicaceae

1. Chenopodium album L. Chenopodiaceae

52. Chenopodium ambrosioides L. Chenopodiaceae

53. Chrozophora rottleri (Geisel.) A. Juss. ex Spreng.

54. Cleome aspera Koenig ex DC.

Euphorbiaceae

55. Cleome gynandra L.

56. Cleome monophylla $\mathrm{L}$.

57. Cleome rutidosperma DC.

58. Cleome spinosa Jacq.

59. Cleome viscosa $\mathrm{L}$

60. Commelina benghalensis L.

61. Corchorus olictres L.

62. Coronopus didymus (L.) Sm

63. Costus speciosus (Koenig.) J.C. Sm.

Capparidaceae

Capparidaceae

Capparidaceae

Capparidaceae

Capparidaceae

Capparidaceae

Commelinaceae

Tiliaceae

Brassicaceae

Cremanthodium arnicoides (DC. ex Royle) R.D. Good.

65. Crinum asiaticum $\mathrm{L}$.

Asteraceae

66. Croton bonplandianum Baillon

67. Curculigo orchioides Gaertn.

68. Cuscuta reflexa Roxb.

69. Datura metel $\mathrm{L}$

70. Dentella repens (L.) Forst.

71. Didymoplexis pallens

72. Dimorphotheca pluvidis (L) Moenc

73. Dischidia benghalensis Colebr.
74. Ecbolium viride (Ferssk.) Alston.

75. Eclipta prostrata (L.) L.

76. Eichhornia crassipes (Mart.) Solms

77. Elephantopus scaber $\mathrm{L}$.

78. Emilia sonchifolia (L) DC

79. Eranthemum pulchellum Andr.

80. Eryngium foetidum $\mathrm{L}$.

81. Eulopbia andamanensis Rchb.f

82. Euphorbia hirta L

83. Euryale ferox Salisb.

84. Evolvulus alsinoides L.

85. Evolvulus nummularius (L.) L.

86. Gazania rigens (L.) Gaertn

87. Gerbera jamesonii Bolus ex Hook.

88. Globba schomburgkii Hook.f

89. Globba marantina L.

90. Gomphrena serrata L.

91. Heliotropium indicum $\mathrm{L}$.

92. Hemidesmus indicus $\mathrm{R}$. Br.

93. Hydrilla verticillata (L.f) Royle

94. Justicia simplex D. Don

95. Kalanchoe pinnata (Lam.) Pers.

96. Laportea interrupta (L.) Chew.

97. Lemna minor L.

98. Leonurus sibiricus L.

99. Lobularia maritima (L.) Desk.

100. Ludwigia adscendens (L.) Hara

101. Ludwigia perennis L.

102. Malvestrum coromandelianum (L.) Garcke

103. Mansoa alliacea (Lam.) A.H. Gentry.

104. Maranta arundinacea L

105. Marsilea quadrifolia (L.) Willd.

106. Medicago lupilina L.

107. Melastoma malabathricum L.

108. Melochia corchorifolia L.

109. Merremia tridentata (L.) Hallier. f.

110. Merremia umbellata (L.) Hallier.f

111. Mikania cordata (Burm.f.) B.L. Rob.

112. Mimosa pudica L.

113. Mirabilis jalapa L.

114. Monochoria hastata (L.) Solms

115. Nelumbo nucifera Gaertn.

116. Nicotiana plumbaginifolia Viv.

117. Nymphaea alba L.

118. Nymphaea pubescens Willd.

119. Nymphaea rubra Roxb. ex Andrews

120. Nymphaea nouchali Burm.f

121. Ocimum gratissimum $\mathrm{L}$.

122. Oldenlandia lacteal (Willd.) DC.

123. Operculina turpetbum (L.) Silva Manso

124. Ottelia alismoides Pers.

125. Oxalis corniculata $\mathrm{L}$.

127. Paederia foetida L.

128. Pancratium pusillum Schum.

129. Parthenium bysterophorus $\mathrm{L}$

130. Passiflora caerulea $\mathrm{L}$.

131. Passiflora geminiflora D.Don

133. Peperomia pellucida (L.) H.B \& K. Piperaceae

134. Phacelia campanularia A. Gray Hydrophyllaceae

135. Phyla nodiflora (L.) Grana

136. Phyllanthus amarus Schum. \& Thonn.

137. Phyllanthus fratesnus Webs.

138. Physalis minima L.

139. Physalis peruviana $\mathrm{L}$.

140. Piper rectrofractum Vahl

141. Piper nigrum $\mathrm{L}$.

142. Pilea microphylla (L.) Liebm.

143. Pistia stratiotes L.

144. Plumbago auriculata Lam.

145. Plumbago zeylanica L.

146. Polygonum barbatum L.

147. Polygonum glabrum Willd.

148. Polygonum orientale $\mathrm{L}$.

149. Porana paniculata Roxb.
Acanthaceae

eriaceae

Asteraceae

Acanthaceae

Apiaceae

(aceae

Euphorbiaceae

Asteraceae

Zingiberaceae

ingiberaceae

aranthaceae

Periplocaceae

Hydrocharitaceae

Acanthaceae

rassulaceae

Urticaceae

(acea

Brassicaceae

Onagraceae

Onagraceae

Malvaceae

Bignoniaceae

Marantaceae

aceae

Sterculiaceae

Convolvulaceae

Nyctaginaceae

Pontederiaceae

Nelumbonaceae

Solanaceae

Nymphaeaceae

Nymphaeaceae

mphaeaceae

ymphaeaceae

Rubiaceae

Convolvulaceae

Hydrocharitaceae

Oxalidacea

Rubiaceae

Amarylladaceae

Asteraceae

Passifloraceae

Verbenaceae

Euphorbiaceae

Euphorbiaceae

Solanaceae

Solanaceae

Piperaceae

Piperaceae

Urticaceae

Araceae

Plumbaginaceae

Plumbaginacae

Polygonaceae

Polygonaceae

Polygonaceae

Convolvulaceae 


\begin{tabular}{|c|c|c|}
\hline 50 . & & Potamogetonacea \\
\hline & Potamogeton nodosus Poir. & Potamogeto \\
\hline & Pothos scandens $\mathrm{L}$. & Araceae \\
\hline & Premna barbata Wall. & Verbenaceae \\
\hline & Premna benghalensis C.B. Cl. & Verbenaceae \\
\hline & Premna corymbosa Rottl. & Verbenaceae \\
\hline & \multicolumn{2}{|c|}{ Primula arvensis E.H.L. KrausePrimulaceae } \\
\hline & \multicolumn{2}{|c|}{ Pseudelephantopus spicatus (Juss. ex Aubl.) Rohr. } \\
\hline & Psorelea corylifolia $\mathrm{L}$. & Fabaceae \\
\hline & Punica granatum $\mathrm{L}$. & Punicaceae \\
\hline ). & \multicolumn{2}{|c|}{ Rauvolfia serpentina Benth ex KurzApocynaceae } \\
\hline . & Rauvolfia tetrapbylla $\mathrm{L}$. & Apocynaceae \\
\hline & \multicolumn{2}{|c|}{ Rbinacanthus nasuta (L.) Kurz. Acanthaceae } \\
\hline & \multicolumn{2}{|c|}{ Rhoed spathacea (Sw.) W.T. StearnCommelinaceac } \\
\hline 164. & \multicolumn{2}{|c|}{ Rivina bengalensis Srivast. \& PaulPhytolaccaceae } \\
\hline . & Rivina bumilis $\mathrm{L}$. & Phytolaccaceae \\
\hline & a bicolor $\mathrm{Nutt}$ & Ast \\
\hline & $\mathrm{R} u$ dbeckia lacinata $\mathrm{L}$. & Asteraceae \\
\hline & \multicolumn{2}{|c|}{ Ruellia neolongifolius Bennet \& Raizada } \\
\hline & & Acanthac \\
\hline & $a \mathrm{~L}$. & Ac \\
\hline & nus $\mathrm{L}$. & naceae \\
\hline 1 & sagittifolia $\mathrm{L}$. & Alismataceae \\
\hline & Salvinia adnata Desv. & Saviniaceae \\
\hline \multicolumn{3}{|c|}{ 173. Salvia splendens Sellow ex Woes Saviniaceae } \\
\hline 74 & Scoparia dulcis $\mathrm{L}$. & Scrophulariaceae \\
\hline & rpurea Dyer & inaceae \\
\hline $1 / 0$. & Sida acuta Burm.f. & Malvaceae \\
\hline \multicolumn{3}{|c|}{ 177. Sida cordata (Burm.f.) Borss. Malvaceae } \\
\hline 170 & Sida cordifolia $\mathrm{L}$. & Malvaceae \\
\hline & ombifolia $\mathrm{L}$. & Malvaceae \\
\hline 1 & Solanum americanum Mill. & Solanaceae \\
\hline & Solanum diphyllum $\mathrm{L}$. & Solan \\
\hline 1 & Sonchus oleraceus L. & Ast \\
\hline & Spathoglottis plicata Bleume & Orchidaceae \\
\hline \multicolumn{3}{|c|}{ 184. Spirodela polyrrbiza (L.) Schiel. Lamiaceae } \\
\hline \multicolumn{3}{|c|}{ 185. Stachytarpheta jamaicensis (L.) Vahl Verbenaceae } \\
\hline & Stapelia gigantea $\mathrm{N} . \&$ Br. & Asclepiadaceae \\
\hline 187 & Stellaria media (L.) Villars & Caryophyllaceae \\
\hline \multirow{2}{*}{\multicolumn{3}{|c|}{188.}} \\
\hline & & \\
\hline \multicolumn{3}{|c|}{ 189. Sulcorebutia mertosa F. RitterCactaceae } \\
\hline & Tacca integrifolia Ker-Gawl. & Taccaceae \\
\hline & Tagetes erecta $\mathrm{L}$. & Asteraceae \\
\hline & Tagetes patula L. & Asteraceae \\
\hline
\end{tabular}

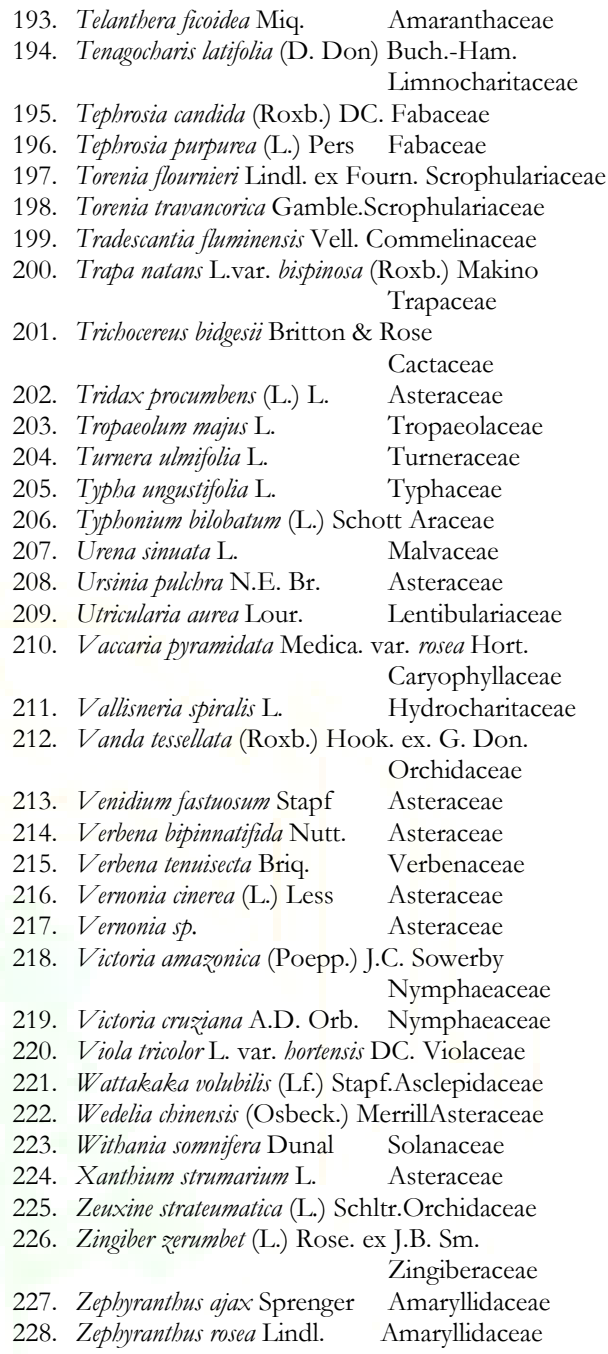




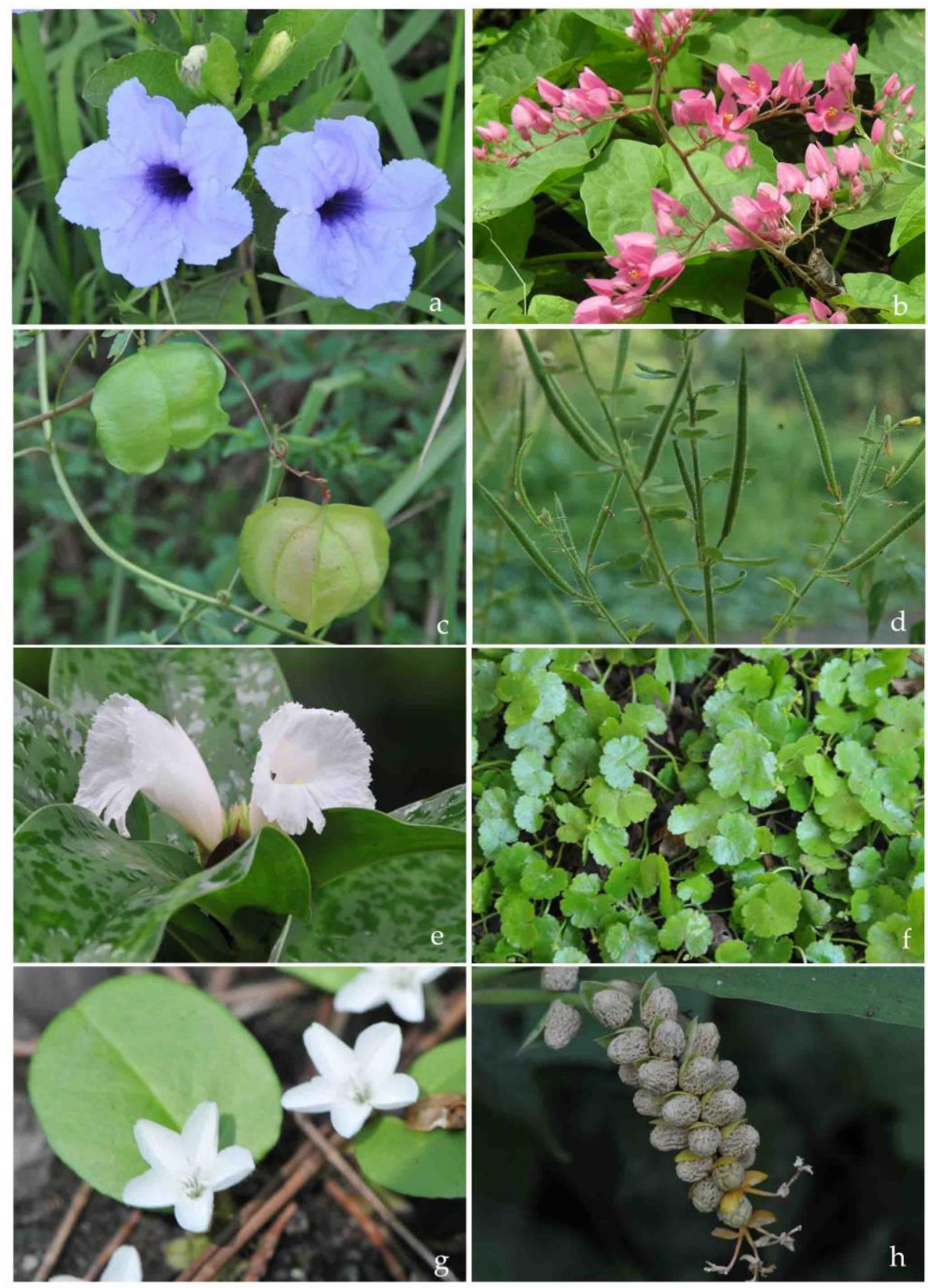

Plate:1. a. Ruellia tuberosa; b. Antigonon leptopus; c. Cardiospermum helicacabum; d. Cleome viscosa; e. Costus speciosus; f. Centella asiatica; g. Evolvulus nummularius; h. Globba schomburgkii. 

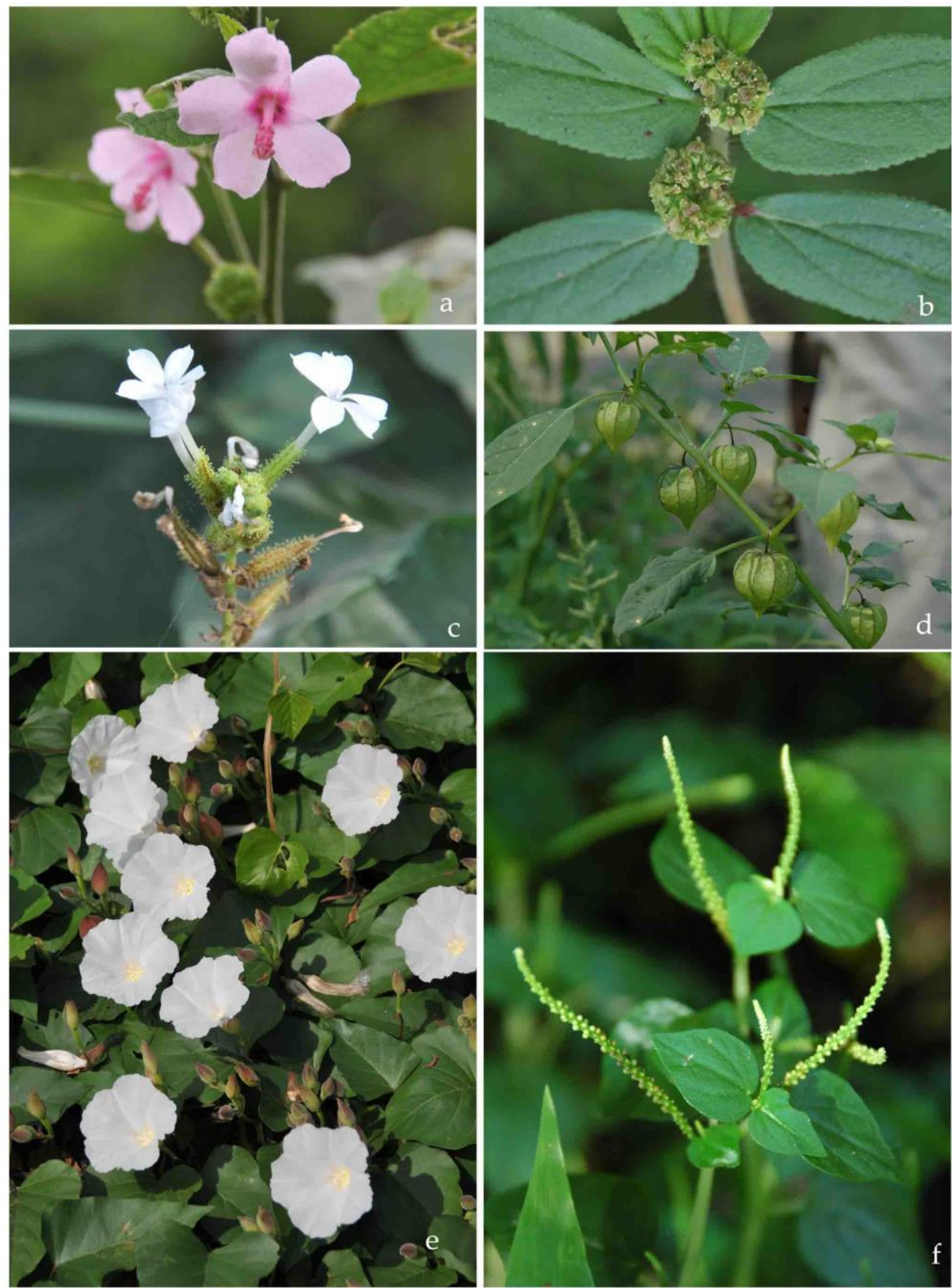

Plate 2: a. Urena sinuata; b. Euphorbia hirta; c. Plumbago zeylanica; d. Physalis minima; e. Operculina turpethum; f. Peperomia pellucida. 


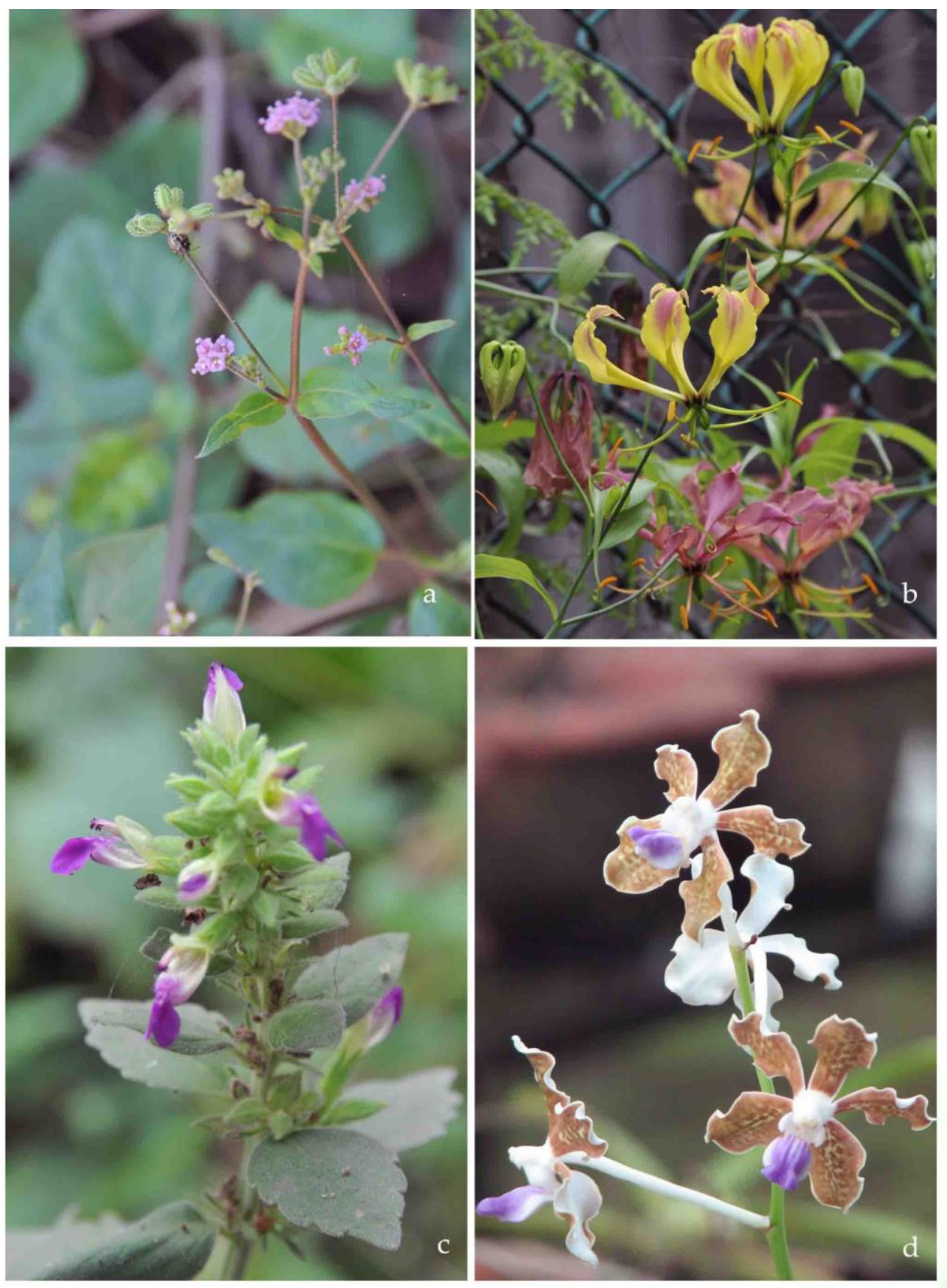

Plate 3: a. Boerhhavia diffusa; b. Gloriosa superba; c. Anisomeles indica; d. Vanda tessellata. 

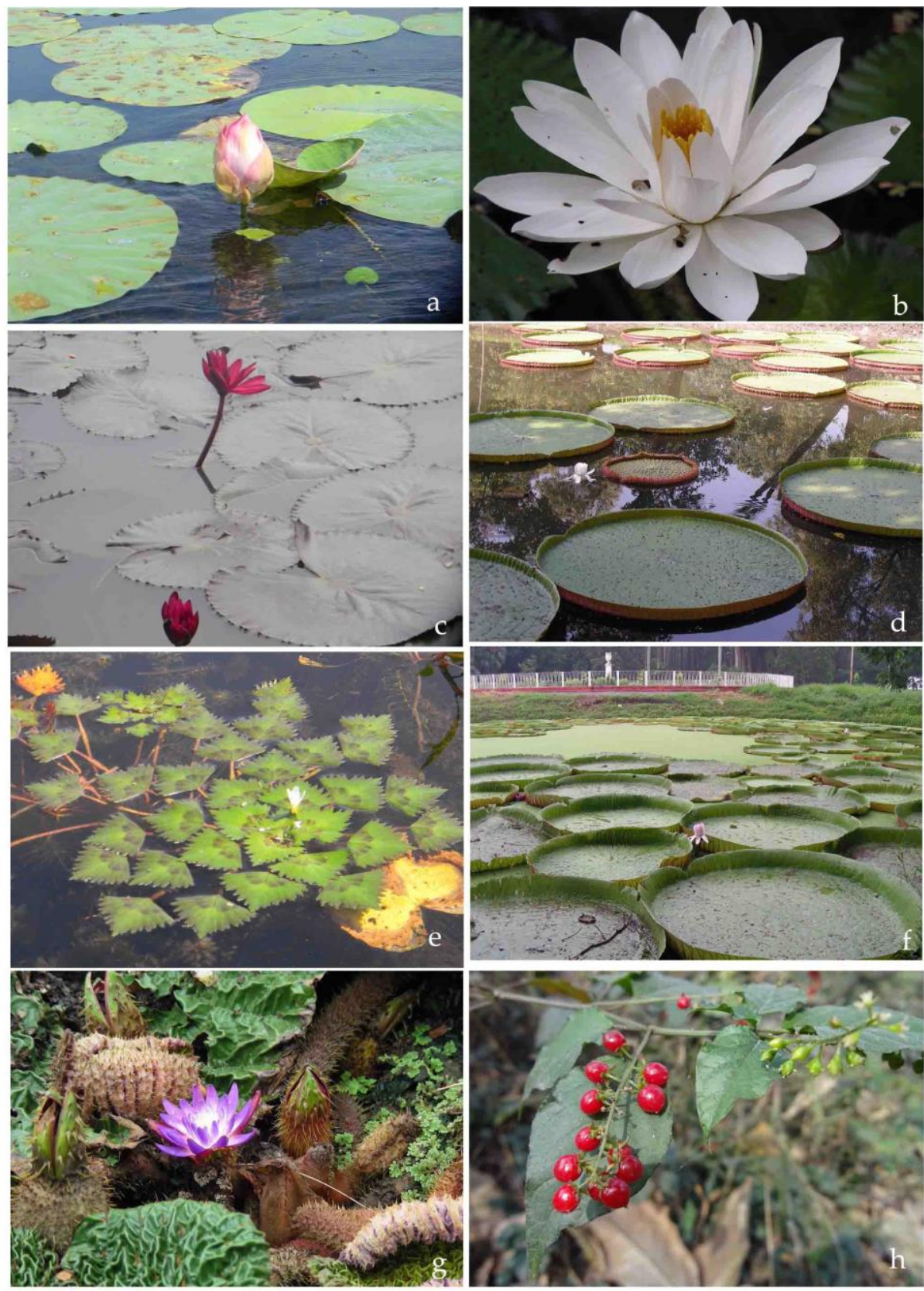

Plate: 4. a. Nelumbo nucifera; b. Nymphaea nouchali; c. Nymphaea pubescens; d. Victoria amazonica; e.Trapa natans var. bispinosa; $\mathrm{f}$. Victoria cruziana; g. Euryale ferox; h. Rivina bengalensis.

\section{Statistical analysis}

During the present survey programme a total of 228 herbaceous species under 181 genera belonging to 78 families have been observed to be growing in the garden including 4 fern species under 3 genera belonging to 3 families. Out of 228 species, 188 species of dicots are distributed under 146 genera belonging to 59 families, while 36 monocot species spread over 32 genera under 16 families. The approximate ratio of monocot and dicot species is 1:5.22. So it indicates that the dicots are represented more than five times than the monocots, which is shown in the Table-1. Out of total 78 families, 34 families are represented by single species. Asteraceae is the first dominant family followed by the families like Acanthaceae, Amaranthaceae, Araceae, Malvaceae, Nymphaeaceae, Solanaceae, Verbenaceae etc. The herbaceous flora is also represented by 4 pteridophytes (ferns) belonging to 3 genera under 3 families. 
Table 1: Percentage of families, genera and species of dicots, monocots and pteridophytes present in AJCBIBG.

\begin{tabular}{lcccccc}
\hline \multirow{2}{*}{ Groups } & \multicolumn{2}{c}{ Families } & \multicolumn{2}{c}{ Genera } & \multicolumn{2}{c}{ Species } \\
\cline { 2 - 7 } & No. & $\mathbf{\%}$ & No. & \% & No. & \% \\
\hline Dicotyledons & 59 & 75.64 & 146 & 80.66 & 188 & 82.45 \\
Monocotyledons & 16 & 20.51 & 32 & 17.67 & 36 & 15.78 \\
Pteridophytes & 03 & 03.84 & 03 & 01.65 & 04 & 01.75 \\
\hline
\end{tabular}

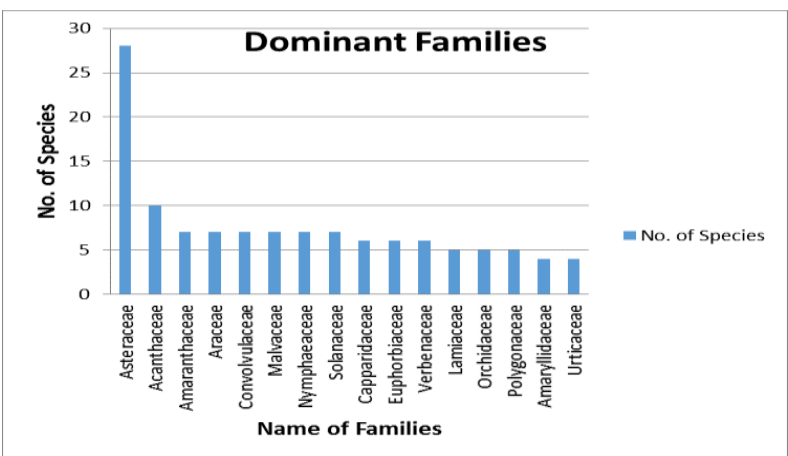

Graph 1: Dominant Families

\section{Conclusion}

The vegetation of the AJCBIBG is mainly of 3 storeyed. The top canopy consists of tree species; shrubs constitute the middle storey while the ground flora inhabited by herbs. The rich tree diversity provides an ideal abode for the growth and development of the herbaceous flora in a way of supplying the congenial climatic conditions. Operculina turpethum (L.) Silva Manso, Asystatia gangetica (L.) T. Anderson, Commelina benghalensis L., Rivina benghalensis Srivast. \& Paul, Euphorbia birta L., Andrographis paniculata (Burm.f) Nees, Costus speciosus (Koenig.) J.C. Sm., Cardiospermum belicacabum L., Gomphrena serrata L., Sida acuta Burm.f., Wedelia chinensis (Osbeck.) Merrill, Tridax procumbens (L.) L., Globba schomburgkii Hook.f, Achyranthes aspera L., Eclipta prostrata (L.) L., Abutilon indicum (L.) Sweet, Evolvulus alsinoides L. etc., are the dominant herb exhibiting luxuriant growth. Post-monsoon period is the best period for the growth of the herbaceous flora. In this period the diversity is very rich. The rich herbaceous cover in turn retains the moisture content, enhances the quality of the soil and checks soil erosion thereby helping the growth and natural regeneration of valued tree species conserved in this historic botanic garden by harboring specific ecological niche. The lakes are also home to many aquatic, semi-aquatic and marshy herbs under the genera Nymphaea, Ipomoea, Hydrilla, Vallisnaria, Utricularia, Limnophylla, Trapa etc. But the lakes are heavily infested with massive growth of invasive exotic weeds like Eichhornia crassipes (Mart.) Solms, Pistia stratiotes L., Salvinia sp. etc. Intrusion of these species into the lakes hampers the growth of the other aquatic flora. Hence, immediate and effective management of these species are essential to provide a chance for establishment of other herbaceous forms.

\section{Acknowledgement}

The authors are thankful to the Director, Botanical Survey of India, Kolkata for encouragement, support and providing infrastructural facilities. Thanks are also due to Mr. Shyam Biswa, Sr. Preservation Assistant, CNH, Howrah for his help.

\section{References}

1. Biswas, K. In proceedings of the $150^{\text {th }}$ anniversary volume of the Royal Botanic Garden, Calcutta; 2a -12 (1938).

2. Chowdhery, H J, and D. S. Pandey. "Plants of Indian Botanic Garden", Botanical Survey of India, Kolkata (2007).

3. Debnath, H, H S Mahapatra, S S Hameed, and P V Sreekumar. "Census of plants in AJC Bose Indian Botanic Garden: A Report”. Botanical Survey of India. Kolkata (2014).

4. Gage, A T. "Catalogue of Non-herbaceous phanerogams cultivated in the Royal Botanic Garden, Calcutta". Records of the Botanical Survey of India, 5. I (1912).

5. Sen, J, and J N Naskar. "Non-herbaceous phanerogams of the Indian Botanic Garden, Calcutta". 7 (1965):31-61.

Cite this article as:

Hameed S.S., Panda S.P., Sharief M.U., Sreekumar P.V., Mahapatra H.S. and A. Pramanik. A preliminary survey of the herbaceous flora of the Acharya Jagadish Chandra Bose Indian Botanic Garden (AJCBIBG), Howrah, W.B., India. Annals of Plant Sciences 5.5 (2016): 1335-1343.

Source of support: Nil

Conflict of interest: None Declared 